\title{
PELATIHAN BAHASA INGGRIS BAGI ANAK - ANAK SEKOLAH MENEGAH PERTAMA DI WEST PRIVATE COURSE
}

\author{
Rohdearni Waty Sipayung, ${ }^{1}$ Tiodora Silalahi ${ }^{2,}$ Marhaeni K.D Matondang ${ }^{3}$, Benarita Purba $^{4}$ \\ ${ }^{1,2,3,4}$ Program Studi Pendidikan Bahasa Inggris, Fakultas Keguruan dan Ilmu Pendidikan \\ Universitas Simalungun \\ e-mail:tiodorasilalahi2@gmail.com
}

\begin{abstract}
Abstrak
Pengabdian masyarakat ini bertujuan untuk melatih dan meningkatkan pemahaman bahasa Inggris Anak- anak Sekolah Menengah Pertama yang ada di WEST PRIVATE COURSE kecamatan Siantar Marihat Pematangsiantar. Adapun masalah yang ditemukan adalah masalah pengetahuan tentang utterances dan pelafalan (pronunciation)yang tidak sesuai menurut aturan yang baik dan benar kemudian kurangnya kemampuan anak- anak yang merupakan peserta yang mengikuti Kursus bahasa Inggris di tempat tersebut, masalah berikutnya adalah siswa siswa sekolah menegah pertama tersebut juga memiliki ketidakmampuan dalam berbicara akibat kosakata yang minim dan mengakibatkan keenganan dalam berkomunikasi secara fasih dan lancer, peserta terdiri dari 25 peserta.Pelatihan dan pendampingan ini dilakukan dengan cara ceramah, praktek/demonstrasi dan latihan yang disertai dengan tanya jawab dalam Bahasa Inggris. Kegiatan ini didukung oleh antusisas peserta,tentor dan manager dari Kursus tersebut. Diharapkan nantinya Pelatihan ini dapat meningkatkan kualitas dan kemampuan berkomunikasi dengan menggunakan bahasa inggris yang baik dan benar. Dengan mengadakan Kegiatan kegiatan yang bermamfaat seperti ini kiranya membantu meningkatkankan prestasi dan kemampuan anak anak dan juga lingkungan sekitar lainnya.
\end{abstract}

Kata Kunci : Pelatihan,Bahasa Inggris, West Private Course

\begin{abstract}
This Community Activity is a service which intend to advance the knowledge and understanding of the students' of West Private Course Siantar Marihat Distric of Pematangsiantar in English. The problems Found were the problem of Knowledge abaout the Utterances and The pronunciation which were not in accordance with good rules and the lack of ability of the children as the participants who attended the English course at the place. Next problem is that these junior high school students also have inability to speak due to minimal vocabulary they and the result in reluctance to cummunicate fluently. There are 25 students involved in this activity and 4 lectures. The objectives of this community activity is to increase the lack of pronunciation in English also The vocabularies and the Use of communication in daily practice.This training andmentoring was carried out by means of lectures, practice/demostrations and exercises accompanied by questions and answers in English.This activity was supported by the enthuasism of the participants, tutors and the manager of the course. It is hoped that laterthis training can improve the quality and ability to communicate using good and acurate English. It is need of a great attention to do this activity and the students hope to be always practice English successfully.
\end{abstract}

Keywords: Training, English, West Private Course

\section{PENDAHULUAN}

Bahasa adalah kemampuan yang dimiliki manusia untuk berkomunikasi dengan manusia lainnya menggunakan tanda, misalnya kata dan gerakan. Perkiraan jumlah bahasa di dunia beragam antara 6.000-7.000 bahasa. Bahasa manusia bersifat independen terhadap modalitas. Sebagai konsep umum, "bahasa" mengacu pada kemampuan kognitif untuk dapat mempelajari dan menggunakan sistem komunikasi yang kompleks, atau untuk menjelaskan sekumpulan aturan yang membentuk sistem tersebut atau sekumpulan pengucapan yang dapat dihasilkan dari aturan-aturan tersebut.

Di era globalisasi perkembangan teknologi semakin berkembang pesat. Perkembangan ini tentu memberi dampak kepada kita semua, baik itu positif maupun negative, perkembangan ini juga menyadarkan kita bahwa persaingan semakin ketat, persaingan bahkan dilakukan dalam kancah 
internasional untuk membawa nama baik Negara kita, kerja sama yang dilakukan bukan lagi kerja sama antar kota, melainkan kerja sama antar Negara.

Dalam pengabdian ini menganalisis Bimbingan Belajar West yang memiliki 1 unit kantor pusat dan 2 kantor cabang. Kantor pusat terletak di kota Medan.Bimbingan West Melanthon Siregar belum melakukan pelatihan bahasa Inggris dengan baik dan lancar yang menyebabkan anak - anak masih menemukan kesulitan dalam berbahasa Inggris dengan fasih dan lancar. Hal ini perlu dilakukan usaha dengan memberikan pelatihan bahasa Inggris bagi anak -anak Sekolah Mengah Pertama . Pelatihan ini diharapkan dapat memberikan manfaat oleh pemilik bimbingan dalam meningkatkan kualitas dan kemampuan berkomunikasi dengan menggunakan bahasa Inggris yang baik dan benar.

Pelatihan bahasa Inggris dilakukan oleh tentor bimbingan West hanya fokus kepada penyelesaian tugas bahasa Inggris sekolah dan juga penyelesaian soal-soal bahasa Inggris. Diperlukan pelatihan berkomunikasi didalam bahasa Inggris yang baik dan benar. Hal ini bertujuan untuk mengetahui seberapa baik kemampuan berbahasa Inggris anak-anak di bimbingan West. Meskipun pada masa pandemic Covid saat ini, Pengelola bimbingan tetap gigih dan ulet dalam menjalankan usaha guna mencerdaskan kehidupan anak bangsa. Dan hal inilah yang memotivasi penulis untuk melakukan kegiatan pengabdian masyarakat pada bimbingan tersebut.

Umumnya tentor atau tenaga pengajar yang diberdayakan di bimbingan belajar West ini adalah lulusan fresh graduate dari beberapa Universitas yang ada di Sumatera. Dari segi pengalaman mengajar kemungkinan besar para tenaga pendidik masih belum matang. Sehingga manajemen bimbingan belajar menemukan kendala dalam penerimaan anak anak bimbingan setiap semesternya.

Berdasarkan identifikasi masalah tersebut, maka yang menjadi rumusan masalah dalam pengabdian ini adalah:

1) Apakah perekrutan tentor atau tenaga pendidik sudah berjalan dengan baik?

2) Apakah metode, strategi, tehnik dan pendekatan pembelajaran sudah dilaksanakan dengan baik?

\section{METODE}

Khalayak sasaran pengabdian pada masyarkat ini tentu saja adalah tentor atau tenaga pendidik pada bimbingan belajar West Kecamatan Siantar Marihat Jl.Melanthon Siregar. Khalayak sasaran diutamakan tentor atau tenaga pendidik khususnya tentor bahasa Inggris. Pelaksanaan pengabdian ini tentu saja melibatkan beberapa pihak. Melalui pengabdian ini diharapkan pengetahuan, wawasan dan kemampuan serta keterampilan dalam mengajar dengan berbasis teknologi semakin meningkat. Permasalahan bahwa para tentor atau tenaga pendidik bimbingan belajar West Kecamatan Siantar marihat Jl. Farel Pasaribu masih kurang memahami tentang metode, strategi, tehnik dan pendekatan dalam pembelajaran. Kegiatan pelaksanaan pengabdian dilakukan dengan tiga tahapan, yang mana tahap pertama merupakan tahap persiapan. Pada tahap ini kelompok pengabdian melakukan survey pendahuluan untuk melihat kondisi dilapangan mengenai proses pembelajaran yang dilakukan oleh tentor atau tenaga pendidik, dengan: 1) Tahap sosialisasi mengenai pentingnya pengetahuan tentang metode, strategi, tehnik dan pendekatan dalam pembelajaran, 2) Tahap kedua memberikan pelatihan kepada tentor atau tenaga pendidik mengenai metode, strategi, tehnik dan pendekatan dalam pembelajaran.

\section{HASIL DAN PEMBAHASAN}

\section{Hasil}

Program pengabdian ini mendapat antusiasme peserta yang cukup tinggi terhadap pelatihan bekomunikasi didalam bahasa Inggris dengan fasih dan lancar. Kegiatan PKM yang dilaksanakan dengan acara tatap muka dan kemudian pelatihan berkomunikasi dalam bahasa Inggris.Peserta pelatihan berjumlah 25 orang dari peserta didik West Course.

\section{Pembahasan}

Pelaksanaan Kegiatan PPM ini dilakukan oleh 4 orang tim pengabdi dengan pokok bahasan yang disampaikan mengenai:

1. Pemamfaatan media dan sarana prasarana yang ada

2. Penerapan tehnik,metode dan strategi pembelajaran

3. Penerapan pendekatan dalam pembelajaran

4. Evaluasi hasil pelatihan yang telah dipraktekkan 
Ketercapaian target pelatihan pada PPM ini cukup baik, karena pelatihan telah dilakukan dengan baik secara keseluruhannya. materi Pendampingan yang telah disampaikan adalah: bahasa Inggris (vocabulary), 2.Pronunciation Practise,3. Classroom action research. Kemampuan Peserta materi masih kurang dikarenakan waktu yang singkat dan kemampuan peserta yang berbeda beda.Secara keseluruhan kegiatan pendampingan pelatihan kemampuan berkomunikasi dalam bahasa Inggris ini dapat dikatakan berhasil. Keberhasilan ini dapat diukur dari kepuasan para peserta setelah mengikuti kegiatan ini.

\section{SIMPULAN}

Kegiatan pengabdian dan pendampingan dapat diselanggarakan dengan baik dan berjalan lancar sesuai dengan rencana kegiatan yang telah disusun meskipun belum semua peserta pendamping menguasai dengan baik bahan yang telah disampaikan. Kegiatan ini mendapat sambutan sangat baik terbukti dengan keaktifan peserta didik mengikuti pelatihan pendampingan.

\section{SARAN}

Berdasarkan evaluasi yang telah dilakukan dapat diajukan beberapa saran sebagai berikut diantaranya adalah: waktu dan pelaksanaan pengabdian perlu ditambahi untuk waktu berikutnya agar tujuan kegiatan, adanya kegiatan lanjutan yang berupa pelatihan sejenis selalu diselenggarakan secara periodik sehingga dapat meningkatkan kemampuan peserta didik di WEST PRIVATE COURSE dalam berkomunikasi didalam bahasa inggris dengan fasih dan lancer

\section{UCAPAN TERIMAKASIH}

Puji dan syukur kami Panjatkan kepada Tuhan yang Maha Esa karena limpahan berkatnya kami Para Dosen dapat mengadakan Kegiatan pengabdian masyrakat dengan judul "PELATIHAN BAHASA INGGRIS BAGI ANAK ANAK SEKOLAH MENEGAH PERTAMA DI WEST PRIVATE COURSE' dimana kegiatan ini berjalan dengan baik dan mendapat sambutan yang sangat baik juga sehingga sesuai dengan yang diharapkan.Kegiatan ini sangat penting dan bertujuan untuk meningkatkan pemahamaman Bahasa inggris pada anak anak ditingkat sekolah menengah pertama.Semoga dilain kesempatan kegiatan kegiatan yang sama boleh dilakukan.Dan Kami para Dosen sangat berterimakasih atas kerjasama seluruh pihat yang terkait dari pimpinan,guru guru dan anak anak yang telah terkait dalam kegiatan ini.

\section{DAFTAR PUSTAKA}

Ades, Sanjaya. 2011. Model model Pembelajaran. Bumi Aksara. Jakarta.

Brookhart, S.M. \& Nitko, A.J. (2014). Educational assessment of students. Pearson Higher Ed.

Hamdayana, Jumanta. 2015. Model dan Metode Pembelajaran Kreatif dan Berkarakter. Ghalia Indonesia: Bogor.

Kurniasih dan Sani, Berlin. 2016. Ragam Pengembangan Model Pembelajaran. Kata Pena.

Slavin, R. E. (2006). Educational psychology: Theory and practice (8th ed.). Boston, MA: Pearson

Sohimin, Aris. 2016. 68 Model Pembelajaran Inovatif Dalam Kurikulum 2013. Yogyakarta: Ar-Ruzz Media.

Trianto. 2010. Model Pembelajaran Terpadu. Jakarta: Bumi Aksara. 